\title{
Direct-Hydrocarbon Proton-Conducting Solid Oxide Fuel Cells
}

\author{
Fan Liu and Chuancheng Duan *
}

check for

updates

Citation: Liu, F.; Duan, C. Direct-Hydrocarbon ProtonConducting Solid Oxide Fuel Cells. Sustainability 2021, 13, 4736. https://doi.org/10.3390/su13094736

Academic Editor: Ryan J. Milcarek

Received: 19 March 2021

Accepted: 21 April 2021

Published: 23 April 2021

Publisher's Note: MDPI stays neutral with regard to jurisdictional claims in published maps and institutional affiliations.

Copyright: (C) 2021 by the authors. Licensee MDPI, Basel, Switzerland. This article is an open access article distributed under the terms and conditions of the Creative Commons Attribution (CC BY) license (https:/ / creativecommons.org/licenses/by/ $4.0 /)$.
The Tim Taylor Department of Chemical Engineering, Kansas State University, Manhattan, KS 66506, USA; fliu@ksu.edu

* Correspondence: cduan@ksu.edu; Tel.: +1-785-532-5587

\begin{abstract}
Solid oxide fuel cells (SOFCs) are promising and rugged solid-state power sources that can directly and electrochemically convert the chemical energy into electric power. Direct-hydrocarbon SOFCs eliminate the external reformers; thus, the system is significantly simplified and the capital cost is reduced. SOFCs comprise the cathode, electrolyte, and anode, of which the anode is of paramount importance as its catalytic activity and chemical stability are key to direct-hydrocarbon SOFCs. The conventional SOFC anode is composed of a Ni-based metallic phase that conducts electrons, and an oxygen-ion conducting oxide, such as yttria-stabilized zirconia (YSZ), which exhibits an ionic conductivity of $10^{-3}-10^{-2} \mathrm{~S} \mathrm{~cm}^{-1}$ at $700{ }^{\circ} \mathrm{C}$. Although YSZ-based SOFCs are being commercialized, YSZ-Ni anodes are still suffering from carbon deposition (coking) and sulfur poisoning, ensuing performance degradation. Furthermore, the high operating temperatures $\left(>700^{\circ} \mathrm{C}\right)$ also pose challenges to the system compatibility, leading to poor long-term durability. To reduce operating temperatures of SOFCs, intermediate-temperature proton-conducting SOFCs (P-SOFCs) are being developed as alternatives, which give rise to superior power densities, coking and sulfur tolerance, and durability. Due to these advances, there are growing efforts to implement proton-conducting oxides to improve durability of direct-hydrocarbon SOFCs. However, so far, there is no review article that focuses on direct-hydrocarbon P-SOFCs. This concise review aims to first introduce the fundamentals of directhydrocarbon P-SOFCs and unique surface properties of proton-conducting oxides, then summarize the most up-to-date achievements as well as current challenges of P-SOFCs. Finally, strategies to overcome those challenges are suggested to advance the development of direct-hydrocarbon SOFCs.
\end{abstract}

Keywords: proton-conducting oxides; direct-hydrocarbons SOFCs; coking; durability

\section{Introduction}

Fossil energy sources, including coal, oil, and natural gas, are currently accounting for $>80 \%$ of the global energy consumption. The rapid growth in fossil fuel extraction, transportation, and consumption is leading to significant anthropogenic climate change and global warming accompanied by the principal $\mathrm{CO}_{2}$ emission [1,2]. Additionally, fossil fuels are not sustainable, and their depletion has been identified as a near-future challenge. Therefore, great efforts have been devoted to ensuring a global economy transition to more efficient utilization of fossil fuels and a low-carbon future [3].

Solid oxide fuel cells (SOFCs) have stimulated great interest in highly efficient energy conversion [4]. As electrochemical energy conversion devices, SOFCs can directly and electrochemically convert the chemical energy stored in fuels into clean electric power without the limitation of the Carnot cycle, which, in turn, leads to higher energy conversion efficiency $(\sim 60 \%)$ than traditional combustion engines [5]. For example, gas turbines are applied to produce electricity from coal or natural gas using the intermediary steam with lower energy efficiency ranging from 30-40\% [6]. Hydrogen is considered as the cleanest fuel, leaving only water as the product, while it is not naturally abundant, and there are many complications in its production, transportation, and storage [7]. Hydrocarbons could offer several attractive advantages over hydrogen, including higher volumetric energy storage density (10.05 kJ/L for hydrogen (LHV) and $36.4 \mathrm{~kJ} / \mathrm{L}$ for natural gas) and lower 
transportation cost. For example, in the USA, natural gas or propane is usually distributed through railroad, truck, tanker ship, or pipelines into urban areas. Direct-hydrocarbon SOFCs are, therefore, one of the most promising power sources, which eliminates the fuel processor units and could be integrated into the current power grid, drastically enhancing energy conversion efficiency and reducing emissions.

The SOFC anode, which functions as the catalyst for reforming fuel streams and the electrode for charge transfer, is critical for high-performing direct-hydrocarbon SOFCs. The current SOFC anode is typically a composite of ceramic and metal (i.e., cermet) that exhibits mixed ionic and electronic conduction. For instance, the YSZ-Ni cermet is widely used as the anode for oxygen-ion SOFCs (O-SOFCs) because of its excellent catalytic activities and high electronic conductivity [8]. Unfortunately, $\mathrm{Ni}$ is vulnerable when exposed to hydrocarbon fuels as it is kinetically favorable for carbon deposition. Additionally, YSZ-Ni anodes are more prone to coking and sulfur poisoning because the relatively acidic surface of YSZ could not contribute to coke mitigation [9-11]. Furthermore, the YSZ-Ni cermet requires an operating temperature of $>700{ }^{\circ} \mathrm{C}$, which could thermodynamically favor the coking ascribed to the pyrolysis of hydrocarbons [12]. Since Ni-based anodes are not perfect for working under hydrocarbons, developing Ni-free or oxide-based anodes are emerging approaches to enhancing the durability of direct-hydrocarbon SOFCs [13]. Despite Ni-free anodes delivering good fuel cell performances under hydrocarbon fuels [14], Ni-free anodes are still far away from commercialization and the cell configuration is limited to electrolytesupported SOFCs. Furthermore, Ni-free anodes need a higher operating temperature $\left(>800{ }^{\circ} \mathrm{C}\right.$ ) to obtain considerable catalytic activities, and thus the costly balance of plant (BOP) components are required. Hence, few Ni-free anodes demonstrate electro-catalytic activity and electronic conductivity that can compete with the current Ni-based anode. Therefore, robust SOFC anodes, which are catalytically active at intermediate operating temperatures, coking and sulfur-tolerant, as well as chemically stable, are essential for direct-hydrocarbon SOFCs. Proton-conducting oxides have been developed for numerous electrochemical devices because of high proton conductivity at 300-650 ${ }^{\circ} \mathrm{C}$ [15-19]. Due to their relatively basic surface for high water-uptake capability, such oxides are recently applied as anodes for direct-hydrocarbon P-SOFCs. SOFCs with proton-conducting oxides have demonstrated excellent power density and long-term durability ( $>1000 \mathrm{~h})$, opening a new pathway for developing durable direct-hydrocarbon P-SOFCs [20-22].

Comprehensive aspects of hydrocarbon-fueled SOFCs [7,23-29] and hydrogen-powered P-SOFCs have been summarized by many review papers [21,30,31]. However, there is still a lack of review centering on the hydrocarbon-fueled P-SOFCs [32]. In this review, the fundamentals and recent progress of the P-SOFC development on hydrocarbon fuels are presented. The current challenges and future perspectives of these promising P-SOFCs are highlighted.

\section{Proton-Conducing Oxides}

The state-of-the-art proton-conducting oxides are $\mathrm{ABO}_{3}$ perovskites, including five compositional groups: yttrium-doped barium zirconate (BZY), yttrium-doped barium cerate (BCY), yttrium- and cerium-doped barium zirconates (BZCY/BCZY), and yttrium-, ytterbium, and cerium-doped barium zirconates (BCZYYb) [18,31,33,34]. Due to the relatively low activation energy of proton conduction $(0.4-0.6 \mathrm{eV})$, the proton-conducting oxides exhibit practically significant proton conductivity $\left(10^{-3}-10^{-2} \mathrm{~S} \mathrm{~cm}^{-1}\right)$ at intermediate operating temperatures $\left(400-600^{\circ} \mathrm{C}\right)[31,35]$.

$$
\mathrm{H}_{2} \mathrm{O}+\mathrm{V}_{\mathrm{O}}^{\bullet \bullet}+\mathrm{O}_{\mathrm{O}}^{\mathrm{X}} \rightarrow 2 \mathrm{OH}_{\mathrm{O}}^{\bullet}
$$

The protons are produced via hydration [31], as shown in Equation (1), where KrögerVink notation is used to describe oxygen vacancy $\mathrm{V}_{\mathrm{O}}^{\bullet \bullet}$, lattice oxygen $\mathrm{O}_{\mathrm{O}}^{\mathrm{X}}$ and proton. This defect reaction indicates oxygen vacancies are required for the formation of protons $\mathrm{OH}_{\mathrm{O}}^{\bullet}$; thus, oxygen vacancy concentration is normally increased by the acceptor doping to 
improve the proton conductivity, i.e., the substitution of the $\mathrm{Zr}^{4+}$ or $\mathrm{Ce}^{4+}$ host with trivalent dopants (e.g., $\mathrm{Y}^{3+} / \mathrm{Yb}^{3+}$ ).

In the 1980s, Iwahara et al. first recognized that BCY is a proton conductor [15]. However, it was noted that $\mathrm{BCY}$ is chemically unstable in the presence of water and carbon dioxide [31,36]. Their poor chemical stability hinders their practical applications and much attention has been shifted to zirconate-based proton conductors, especially BZY, due to their enhanced chemical stability [16]. However, with the increased concentration of $\mathrm{Zr}^{4+}$, its poor sintering ability tends to be a thorny issue. Additionally, BZY displays high grain boundary resistance, resulting in lower proton conductivity than $\mathrm{BCY}$ [31]. The researchers, therefore, developed $\mathrm{BCZY}$ by synergizing the benefits of both $\mathrm{BZY}$ and $\mathrm{BCY}$, improving conductivity and stability [16]. Liu et al. demonstrated that $\mathrm{BaCe}_{0.7} \mathrm{Zr}_{0.1} \mathrm{Y}_{0.2} \mathrm{O}_{3}$ possesses improved chemical stability under $2 \% \mathrm{CO}_{2}$ and $15 \% \mathrm{H}_{2} \mathrm{O}$ atmosphere and enhanced conductivity $\left(9 \times 10^{-3} \mathrm{~S} \mathrm{~cm}^{-1}\right)$ at $500{ }^{\circ} \mathrm{C}$ [17]. The same team then pioneered a novel proton conductor, $\mathrm{BaCe}_{0.7} \mathrm{Zr}_{0.1} \mathrm{Y}_{0.1} \mathrm{Yb}_{0.1} \mathrm{O}_{3}$ [18], leading to benchmarking proton conductivity and stability under hydrocarbons with hydrogen sulfide.

To tackle the issues associated with sintering, a sintering aid (e.g., $\mathrm{ZnO}$ ) was added to facilitate the densification and lower the sintering temperatures, increasing the feasibility of using proton-conducting oxides for building fuel cells [37]. A variety of other sintering aids, including $\mathrm{NiO}$ and $\mathrm{CuO}$, have also been investigated for fabricating proton-conducting oxides [38]. In 2015, Duan and O'Hayre et al. [22] applied the solid-state reactive sintering method to P-SOFCs fabrication and demonstrated P-SOFCs with remarkable performances and durability with both hydrogen and methane as fuels.

\section{Unique Surface Properties of Proton-Conducting Oxides}

It has been recognized that increasing the basicity of the catalyst surface can suppress coking over heterogeneous catalysts [10]. Tatsuya et al. [39] investigated the catalytic activity and coking tolerance of Ni-YSZ cermet decorated with four alkaline oxides, including $\mathrm{MgO}, \mathrm{CaO}, \mathrm{SrO}$, and $\mathrm{CeO}$. $\mathrm{CaO}$ was identified as the most effective in improving coking tolerance, although it slightly deteriorated the electrochemical activity of the anode. Liu et al. [40] later demonstrated that the modification of the Ni + YSZ anode with nanostructured $\mathrm{BaO}$, which also has a relatively basic surface, could greatly suppress the coke formation. Density functional theory suggests that $\mathrm{BaO}$ is capable of absorbing and dissociating water and, thereby, enabling coke mitigation. The water-mediated carbon removal mechanism is illustrated in Figure 1. (1) The basic surface of $\mathrm{BaO}$ promotes the dissociation of water into $\mathrm{OH}^{*}$ and $\mathrm{H}^{*}$ over the catalyst ( ${ }^{*}$ indicates the surface site of catalyst); (2) $\mathrm{OH}^{*}$ absorbed on $\mathrm{BaO}$ will then react with carbon deposited on the $\mathrm{Ni}$ and produce $\mathrm{CO}^{*}$ and $\mathrm{H}^{*}$. (3) $\mathrm{CO}^{*}$ and $\mathrm{H}^{*}$ will subsequently react with the oxygen ions at the triple phase boundary and form $\mathrm{CO}_{2}$ and $\mathrm{H}_{2} \mathrm{O}$.

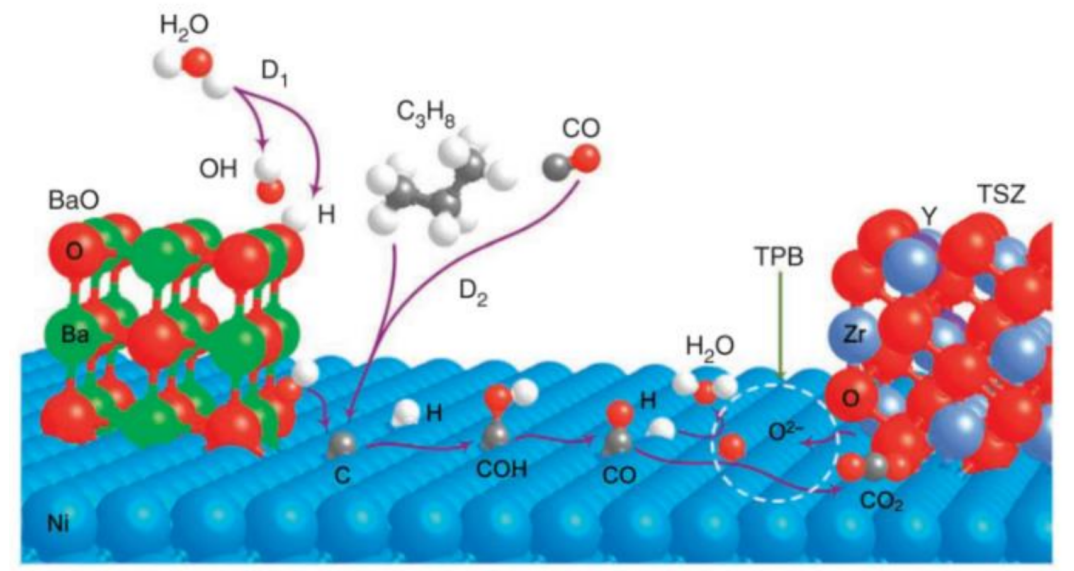

Figure 1. Proposed mechanism for water-mediated carbon removal on the anode with $\mathrm{BaO} / \mathrm{Ni}$ interfaces [40]. 
Surface-enhanced Raman Spectrology (SERS) was employed to better understand the coke mitigation mechanisms of Ni-based anodes coated with $\mathrm{BaO}, \mathrm{BZY}$, and $\mathrm{BCZYYb}$, respectively [41], revealing that abundant $-\mathrm{OH}$ is absorbed on all three materials. These absorbed $-\mathrm{OH}$ can readily react with carbon and subsequently clean coke. However, $\mathrm{BaO}$ can also easily react with $\mathrm{CO}_{2}$ and form $\mathrm{BaCO}_{3}$, which is irreversible, leading to exacerbated SOFC performance degradation. Unlike $\mathrm{BaO}, \mathrm{BZY}$ and $\mathrm{BCZYYb}$ are capable of regenerating $-\mathrm{OH}$ groups, and proton-conducting oxides also have basic surfaces, indicating they could be adopted as the materials for direct-hydrocarbons/ethanol SOFCs. Liu et al. integrated BZCY-Ni with SDC as the anode of direct-ethanol SOFCs, aiming to improve its coking tolerance. They demonstrated ethanol-fueled SOFCs with a power density of $750 \mathrm{~mW} \mathrm{~cm}{ }^{-2}$ at $750{ }^{\circ} \mathrm{C}$ and a stable operation of $170 \mathrm{~h}$. A similar water-mediated carbon removal mechanism was also proposed in this work, suggesting proton-conducting oxides (i.e., BZCY) with high water uptake capacity could accelerate the formation of $\mathrm{C}-\mathrm{OH}$ intermediates and consequently enhance the carbon removal ability. Furthermore, it has been noted that proton-conducting oxides, such as $\mathrm{BCZYYb}$, can also absorb $\mathrm{CO}_{2}$ and form $-\mathrm{CO}_{3}$ groups, which can help to clean the carbon, further improving the coking tolerance [18].

\section{The Rationale for Developing Direct-Hydrocarbon P-SOFCs}

Although P-SOFCs are a nascent technology, they already show significant promise for highly efficient and durable power generation $[19,20,22,32,34,42,43]$. Compared to high-temperature oxygen-ion solid oxide cells (O-SOFCs) and low-temperature polymer electrolyte membrane fuel cells (PEMFCs) or alkaline fuel cells, P-SOFCs offer several important benefits:

1. Unlike O-SOFCs (Figure 2b), as illustrated in Figure 2a, P-SOFCs can produce water in the cathode, which will not dilute the fuel stream, potentially improving the performances, enhancing fuel utilization, and reducing system complexity and cost (that is, no external condenser required for condensing water and recycling fuel), as well as enhancing overall energy efficiency $[4,44]$.

2. Intermediate-temperature P-SOFCs $\left(500-600^{\circ} \mathrm{C}\right)$ enable significantly higher efficiency than low temperature $\left(50-100{ }^{\circ} \mathrm{C}\right)$ PEMFCs and can approach that of HT-SOFCs $\left(700-900^{\circ} \mathrm{C}\right)[45,46]$. Reduced operating temperatures (versus O-SOFCs) enable the relaxing of the stack and balance-of-plant constraints, potentially lowering the cost while also improving the reliability, thermal cycling tolerance, and dynamic response.

3. High hydrocarbon conversion could be achieved in the P-SOFCs because of the continuous removal of hydrogen from the anode which shifts the reaction equilibriums of steam reforming and water gas shift reaction [22].

4. As shown in Figure 3 [20], the composition of P-SOFC anode gas stream lies in the thermodynamic coking boundary of the whole reaction range or just outside it. On the contrary, with increasing the fuel utilization, the composition of anode gas steam in O-SOFC moves away from the coking boundary rapidly. However, the experimental studies of P-SOFCs contradicts the thermodynamic predictions [20,22,34,43], which is due to unique surface properties of proton-conducting oxides. P-SOFCs are therefore coking and sulfur tolerant, and highly active for internal reforming. 
(a)

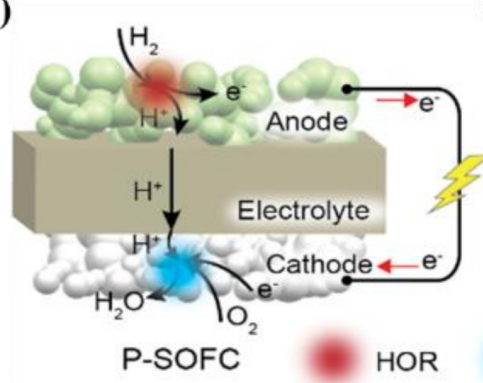

(b)

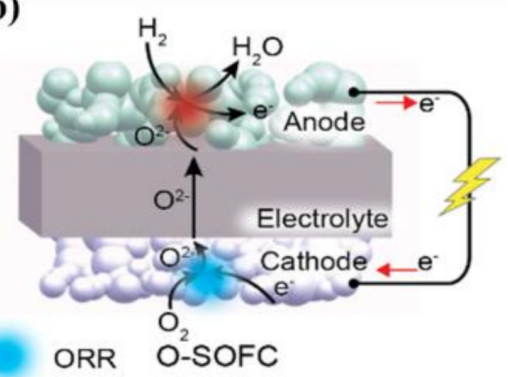

Figure 2. Schematic illustration of SOFCs with (a) a proton-conducting electrolyte; (b) an oxygenion conductor.

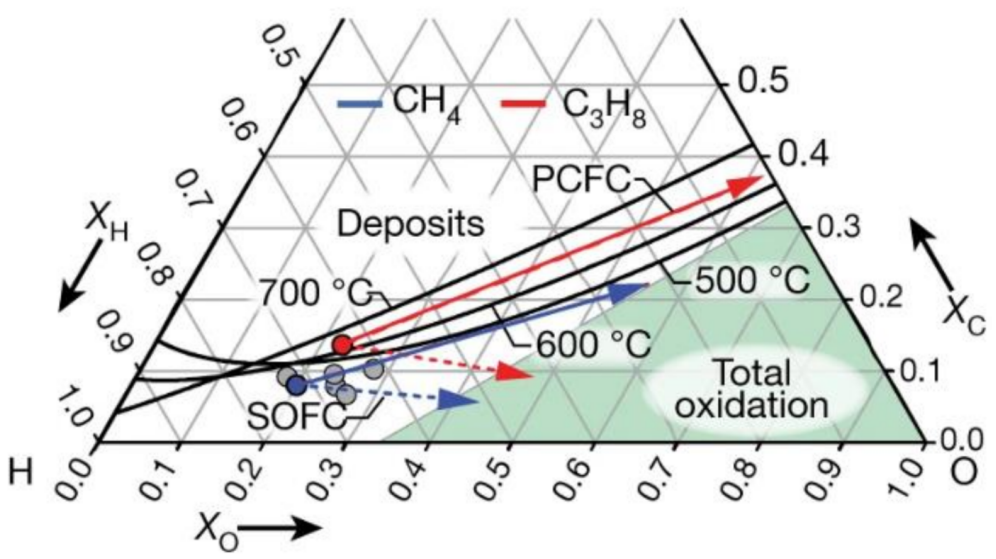

Figure 3. The ternary diagram shows the regions of equilibrium carbon formation and full oxidation. The dots indicate experimental fuel compositions. Fuel composition trajectories for propane (red) and methane (blue) are shown as solid lines for P-SOFCs (increasing current density and removing $\mathrm{H}$ ) and dashed lines for O-SOFC (increasing current density and adding $\mathrm{O}$ ). The end-point compositions correspond to the complete oxidation of the fuel stream to $\mathrm{CO}_{2}$ and $\mathrm{H}_{2} \mathrm{O}$. 'Deposits' indicates the region where coking is thermodynamically favorable [20].

\section{Notable Achievements on Coking-Tolerant Direct-Hydrocarbon P-SOFCs}

Both P-SOFCs and O-SOFCs are capable of directly converting methane and other hydrocarbon fuels (e.g., $\mathrm{C}_{2} \mathrm{H}_{6}$ and $\mathrm{C}_{3} \mathrm{H}_{8}$ ) into electricity. However, coking on YSZ-Ni anode, which blocks the active sites at the triple phase boundary (TPB), results in severe degradation. This is the main obstacle to the commercialization of SOFCs. For example, Yang et al. [40] reported that the terminal voltage of O-SOFCs, when fed with dry $\mathrm{C}_{3} \mathrm{H}_{8}$, quickly dropped to nearly zero at a current density of $500 \mathrm{~mA} \mathrm{~cm}{ }^{-2}$ within the $30 \mathrm{~min}$ operation. There are, therefore, increasing efforts devoted to developing alternative directhydrocarbon fuel cells, such as P-SOFCs.

Direct-methane P-SOFCs were firstly validated by Coors in 2003. Although the current densities are too low to be commercially visible at that time, it has been demonstrated that PSOFC shows the unique coking resistance [47]. Luo et al. [2] proved the feasibility of using propane as the fuel in P-SOFCs, achieving improved fuel cell performances [48]. Duan and $\mathrm{O}^{\prime}$ Hayre et al. [22] employed solid state reactive sintering to fabricate P-SOFCs, tackling the manufacturing challenges arising from the poor sintering ability of proton-conducting oxides. Additionally, they deliberately designed one of the state-of-the-art triple-conducting (oxygen ion, proton, and electron hole) cathodes $\left(\mathrm{BaCe}_{0.4} \mathrm{Fe}_{0.4} \mathrm{Zr}_{0.1} \mathrm{Y}_{0.1} \mathrm{O}_{3}\right.$ ), significantly improving the performances of P-SOFCs. Direct-methane P-SOFCs with remarkable performances and a stable operation of $1400 \mathrm{~h}$ at $500{ }^{\circ} \mathrm{C}$ were demonstrated [22]. In 2017, Liu et al. [49] reported $\mathrm{BaCe}_{0.7} \mathrm{Zr}_{0.1} \mathrm{Y}_{0.2} \mathrm{O}_{3-\delta}$ electrolyte-supported cells with a peak power density of $348.84 \mathrm{~mW} \mathrm{~cm}^{-2}$ and $496.2 \mathrm{~mW} \mathrm{~cm}^{-2}$ on ethane and hydrogen, respectively at 
$750{ }^{\circ} \mathrm{C}$. More recently, the long-term durability of fuel-flexible P-SOFCs has been comprehensively investigated. P-SOFCs fueled with 12 different fuel streams, including hydrogen, methane, natural gas, propane, $n$-butane, $\mathrm{i}$-butane, iso-octane, and others, exhibit a degradation rate of $<1.5 \%$ per $1000 \mathrm{~h}$ for most fuels at $500-600{ }^{\circ} \mathrm{C}$ [20]. This entire set of durability measurements have fully validated that direct-hydrocarbon P-SOFCs are exceptionally stable. In addition to power generation, Luo et al. revealed that P-SOFCs can simultaneously generate power and produce chemicals [50]. Both outstanding fuel cell performances and syngas production rate have been achieved. The performances of hydrocarbon fueled P-SOFCs are summarized in Table 1.

Table 1. Performances of P-SOFCs fed with hydrocarbon fuels.

\begin{tabular}{|c|c|c|c|c|c|}
\hline Year & $\begin{array}{l}\text { Anode/ } \\
\text { Electrolye/ } \\
\text { Cathode }\end{array}$ & Fuel & $\begin{array}{l}\text { Peak Power } \\
\text { Density } \\
\left(\mathrm{mW} \mathrm{cm}^{-2}\right)\end{array}$ & Stability & Reference \\
\hline 2003 & $\mathrm{Ni} / \mathrm{BCY} / \mathrm{Pt}$ & $\mathrm{CH}_{4}$ & $\sim 13$ at $700{ }^{\circ} \mathrm{C}$ & - & [47] \\
\hline 2008 & $\mathrm{Pt} / \mathrm{BCY} / \mathrm{Pt}$ & $\mathrm{C}_{3} \mathrm{H}_{8}$ & $\sim 43$ at $650{ }^{\circ} \mathrm{C}$ & - & [2] \\
\hline 2015 & $\begin{array}{l}\text { Ni-BZY20/ } \\
\text { BZY20/ } \\
\text { BCFZY }\end{array}$ & $\begin{array}{l}28.6 \% \mathrm{CH}_{4}+ \\
71.4 \% \mathrm{H}_{2} \mathrm{O}\end{array}$ & 142 at $500^{\circ} \mathrm{C}$ & $\begin{array}{l}\text { No degredation for } 200 \mathrm{~h} \text {, } \\
0.15 \mathrm{~A} \mathrm{~cm}^{-2} \text { at } 500{ }^{\circ} \mathrm{C}\end{array}$ & [22] \\
\hline 2016 & $\begin{array}{l}\text { Ni-BCZY/ } \\
\text { BCZY/ } \\
\text { PSCFM }\end{array}$ & $\mathrm{C}_{2} \mathrm{H}_{6}$ & $\begin{array}{l}120 \text { at } 650^{\circ} \mathrm{C} \\
349 \text { at } 7500^{\circ} \mathrm{C}\end{array}$ & $\begin{array}{l}\text { No degredation for } 200 \mathrm{~h}, \\
0.65 \mathrm{~A} \mathrm{~cm}^{-2} \text { at } 750{ }^{\circ} \mathrm{C}\end{array}$ & [49] \\
\hline 2016 & $\begin{array}{c}\text { Ni-BCZYYb/ } \\
\text { BCZYYb/ } \\
\text { BCZY-LSCF }\end{array}$ & $\mathrm{CH}_{4}\left(3 \% \mathrm{H}_{2} \mathrm{O}\right)$ & $\begin{array}{l}800 \text { at } 650{ }^{\circ} \mathrm{C} \\
560 \text { at } 600^{\circ} \mathrm{C} \\
320 \text { at } 550{ }^{\circ} \mathrm{C}\end{array}$ & $\begin{array}{l}\text { No degradation for } 200 \mathrm{~h} \text {, } \\
0.50 \mathrm{~A} \mathrm{~cm}^{-2} \text { at } 550^{\circ} \mathrm{C}\end{array}$ & [50] \\
\hline 2016 & $\begin{array}{c}\text { PBMn-Ni- } \\
\text { BCZYYb/ } \\
\text { BCZYYb/ } \\
\text { BCZY+ } \\
\text { NBCCo }\end{array}$ & $\begin{array}{c}50 \% \mathrm{CH}_{4} \\
+50 \% \mathrm{CO}_{2}\end{array}$ & 560 at $700^{\circ} \mathrm{C}$ & $\begin{array}{c}\text { No degradation for } 36 \mathrm{~h}, 1.0 \mathrm{~A} \mathrm{~cm}^{-2} \\
\text { at } 700{ }^{\circ} \mathrm{C}\end{array}$ & [42] \\
\hline 2017 & $\begin{array}{c}\mathrm{Ni}^{-} \\
\text {BCZYYb/BZCY- } \\
\text { LSGM/BZCY- } \\
\text { LSCF }\end{array}$ & $\begin{array}{c}\text { Humidified } 60 \% \\
\mathrm{CH}_{4}^{+} \\
40 \% \mathrm{CO}_{2}\end{array}$ & $\begin{array}{l}210 \text { at } 500{ }^{\circ} \mathrm{C} \\
320 \text { at } 550{ }^{\circ} \mathrm{C} \\
560 \text { at } 600{ }^{\circ} \mathrm{C}\end{array}$ & $\begin{array}{c}\text { No degradation for } 80 \mathrm{~h}, 1.5 \mathrm{~A} \mathrm{~cm}^{-2} \\
\text { at } 650{ }^{\circ} \mathrm{C}\end{array}$ & [51] \\
\hline 2018 & $\begin{array}{l}\text { Ni-BZY/ } \\
\mathrm{BZY} / \mathrm{BCFZY}\end{array}$ & $\begin{array}{l}\text { Natural gas with } \\
19.5 \text { p.p.m. } \mathrm{H}_{2} \mathrm{~S} \\
\text { impurity }\end{array}$ & 372 at $600{ }^{\circ} \mathrm{C}$ & $\begin{array}{l}\sim 10 \% \text { degradation for } 1000 \mathrm{~h}, \\
0.25 \mathrm{~A} \mathrm{~cm}^{-2} \text { at } 500{ }^{\circ} \mathrm{C}\end{array}$ & [20] \\
\hline 2018 & $\begin{array}{l}\text { Ni-BZY/BZY/ } \\
\text { LSCF-PNM }\end{array}$ & $\begin{array}{c}33 \% \mathrm{CH}_{4}+33 \% \\
\mathrm{H}_{2} \mathrm{O}+33 \% \mathrm{~N}_{2}\end{array}$ & $\begin{array}{l}55 \text { at } 550{ }^{\circ} \mathrm{C} \\
96 \text { at } 600{ }^{\circ} \mathrm{C} \\
132 \text { at } 6500^{\circ} \mathrm{C}\end{array}$ & $\begin{array}{l}\text { No degradation for } 20 \mathrm{~h}, 0.6 \mathrm{~V} \text { at } \\
5550^{\circ} \mathrm{C}\end{array}$ & [52] \\
\hline
\end{tabular}

To improve the durability of direct-hydrocarbon O-SOFCs, proton-conducting oxides have also been used for decorating the anode of O-SOFCs [53,54]. Proton-conducting nanoparticles are infiltrated into the anode and distributed over the Ni particles. These proton-conducing nanoparticles with basic surface can absorb and dissociate water, as abovementioned, which subsequently react with deposited carbon or sulfur; thus, this approach alleviates coking and sulfur poisoning. For example, the peak power density of direct-methane SOFCs at $650{ }^{\circ} \mathrm{C}$ was improved from $0.62 \mathrm{~W} \mathrm{~cm}^{-2}$ to $1.27 \mathrm{~W} \mathrm{~cm}^{-2}$ after decorating the Ni-GDC anode with $\mathrm{BCY}$ particles, indicative of the bifunctionality of proton-conducting oxides [53].

\section{Conclusions and Perspectives}

Due to the unique surface properties of proton-conducting oxides, P-SOFCs are one of the keys enabling technologies for directly and efficiently converting hydrocarbons into electricity. Although significant progress has been made in developing advanced proton-conducting oxides, there is a lack of material with both high proton conductivity and great chemical stability under more realistic working conditions, such as fuel streams 
containing high-concentration impurities $\left(\mathrm{CO}_{2}, \mathrm{NO} x\right.$, and $\left.\mathrm{H}_{2} \mathrm{~S}\right)$. Additional efforts are, therefore, urgently required for the development of proton-conducing oxides with higher proton conductivity, improved chemical stability, and enhanced sinterability, as well as P-SOFCs with novel structures, higher performances, and longer lifetime.

Author Contributions: F.L. led the manuscript writing. C.D. and F.L. developed the intellectual concept of this manuscript. C.D. led the manuscript refinement. All authors have read and agreed to the published version of the manuscript.

Funding: This research was funded by Kansas State University tenure track faculty research funding.

Data Availability Statement: Not applicable.

Acknowledgments: F.L. acknowledges the scholarship from the China Scholarship Council (CSC).

Conflicts of Interest: The authors declare no conflict of interest.

\section{References}

1. Lelieveld, J.; Klingmüller, K.; Pozzer, A.; Burnett, R.T.; Haines, A.; Ramanathan, V. Effects of fossil fuel and total anthropogenic emission removal on public health and climate. Proc. Natl. Acad. Sci. USA 2019, 116, 7192. [CrossRef] [PubMed]

2. Feng, Y.; Luo, J.; Chuang, K.T. Propane Dehydrogenation in a Proton-conducting Fuel Cell. J. Phys. Chem. C 2008, 112, 9943-9949. [CrossRef]

3. Abdelkareem, M.A.; Elsaid, K.; Wilberforce, T.; Kamil, M.; Sayed, E.T.; Olabi, A. Environmental aspects of fuel cells: A review. Sci. Total Environ. 2021, 752, 141803. [CrossRef] [PubMed]

4. O'hayre, R.; Cha, S.-W.; Colella, W.; Prinz, F.B. Fuel Cell Fundamentals; John Wiley \& Sons: Hoboken, NJ, USA, 2016.

5. Abdalla, A.M.; Hossain, S.; Petra, P.M.; Ghasemi, M.; Azad, A.K. Achievements and trends of solid oxide fuel cells in clean energy field: A perspective review. Front. Energy 2020, 14, 359-382. [CrossRef]

6. Steele, B.C.H.; Heinzel, A. Materials for fuel-cell technologies. Nature 2001, 414, 345-352. [CrossRef] [PubMed]

7. McIntosh, S.; Gorte, R.J. Direct Hydrocarbon Solid Oxide Fuel Cells. Chem. Rev. 2004, 104, 4845-4866. [CrossRef] [PubMed]

8. Yue, W.; Li, Y.; Zheng, Y.; Wu, T.; Zhao, C.; Zhao, J.; Geng, G.; Zhang, W.; Chen, J.; Zhu, J.; et al. Enhancing coking resistance of Ni/YSZ electrodes: In situ characterization, mechanism research, and surface engineering. Nano Energy 2019, 62, 64-78. [CrossRef]

9. Viinikainen, T.; Rönkkönen, H.; Bradshaw, H.; Stephenson, H.; Airaksinen, S.; Reinikainen, M.; Simell, P.; Krause, O. Acidic and basic surface sites of zirconia-based biomass gasification gas clean-up catalysts. Appl. Catal. A Gen. 2009, 362, 169-177. [CrossRef]

10. Boldrin, P.; Ruiz-Trejo, E.; Mermelstein, J.; Bermúdez Menéndez, J.M.; Ramírez Reina, T.; Brandon, N.P. Strategies for Carbon and Sulfur Tolerant Solid Oxide Fuel Cell Materials, Incorporating Lessons from Heterogeneous Catalysis. Chem. Rev. 2016, 116, 13633-13684. [CrossRef]

11. Skafte, T.L.; Blennow, P.; Hjelm, J.; Graves, C. Carbon deposition and sulfur poisoning during $\mathrm{CO}_{2}$ electrolysis in nickel-based solid oxide cell electrodes. J. Power Sources 2018, 373, 54-60. [CrossRef]

12. Wei, K.; Wang, X.; Budiman, R.A.; Kang, J.; Lin, B.; Zhou, F.; Ling, Y. Progress in Ni-based anode materials for direct hydrocarbon solid oxide fuel cells. J. Mater. Sci. 2018, 53, 8747-8765. [CrossRef]

13. Wang, W.; Qu, J.; Julião, P.S.B.; Shao, Z. Recent Advances in the Development of Anode Materials for Solid Oxide Fuel Cells Utilizing Liquid Oxygenated Hydrocarbon Fuels: A Mini Review. Energy Technol. 2019, 7, 33-44. [CrossRef]

14. Da Silva, F.S.; de Souza, T.M. Novel materials for solid oxide fuel cell technologies: A literature review. Int. J. Hydrogrn Energy 2017, 42, 26020-26036. [CrossRef]

15. Iwahara, H.; Uchida, H.; Ono, K.; Ogaki, K. Proton Conduction in Sintered Oxides Based on BaCeO 3 . J. Electrochem. Soc. 1988, 135, 529-533. [CrossRef]

16. Katahira, K.; Kohchi, Y.; Shimura, T.; Iwahara, H. Protonic conduction in Zr-substituted BaCeO3. Solid State Ion. 2000, 138, 91-98. [CrossRef]

17. Zuo, C.; Zha, S.; Liu, M.; Hatano, M.; Uchiyama, M. Ba $\left(\mathrm{Zr}_{0.1} \mathrm{Ce}_{0.7} \mathrm{Y}_{0.2}\right) \mathrm{O}_{3-\delta}$ as an Electrolyte for Low-Temperature Solid-Oxide Fuel Cells. Adv. Mater. 2006, 18, 3318-3320. [CrossRef]

18. Yang, L.; Wang, S.; Blinn, K.; Liu, M.; Liu, Z.; Cheng, Z.; Liu, M. Enhanced Sulfur and Coking Tolerance of a Mixed Ion Conductor for SOFCs: $\mathrm{BaZr}_{0.1} \mathrm{Ce}_{0.7} \mathrm{Y}_{0.2-x} \mathrm{O}_{3-\delta}$. Science 2009, 326, 126. [CrossRef]

19. Choi, S.; Kucharczyk, C.J.; Liang, Y.; Zhang, X.; Takeuchi, I.; Ji, H.-I.; Haile, S.M. Exceptional power density and stability at intermediate temperatures in protonic ceramic fuel cells. Nat. Energy 2018, 3, 202-210. [CrossRef]

20. Duan, C.; Kee, R.J.; Zhu, H.; Karakaya, C.; Chen, Y.; Ricote, S.; Jarry, A.; Crumlin, E.J.; Hook, D.; Braun, R.; et al. Highly durable, coking and sulfur tolerant, fuel-flexible protonic ceramic fuel cells. Nature 2018, 557, 217-222. [CrossRef]

21. Fabbri, E.; Pergolesi, D.; Traversa, E. Materials challenges toward proton-conducting oxide fuel cells: A critical review. Chem. Soc. Rev. 2010, 39, 4355-4369. [CrossRef]

22. Duan, C.; Tong, J.; Shang, M.; Nikodemski, S.; Sanders, M.; Ricote, S.; Almansoori, A.; O’Hayre, R. Readily processed protonic ceramic fuel cells with high performance at low temperatures. Science 2015, 349, 1321. [CrossRef] [PubMed] 
23. Mogensen, M.; Kammer, K. Conversion of Hydrocarbons in Solid Oxide Fuel Cells. Annu. Rev. Mater. Res. 2003, 33, 321-331. [CrossRef]

24. Kee, R.J.; Zhu, H.; Goodwin, D.G. Solid-oxide fuel cells with hydrocarbon fuels. Proc. Combust. Inst. 2005, 30, 2379-2404. [CrossRef]

25. Ge, X.-M.; Chan, S.-H.; Liu, Q.-L.; Sun, Q. Solid Oxide Fuel Cell Anode Materials for Direct Hydrocarbon Utilization. Adv. Energy Mater. 2012, 2, 1156-1181. [CrossRef]

26. Saadabadi, S.A.; Thallam Thattai, A.; Fan, L.; Lindeboom, R.E.F.; Spanjers, H.; Aravind, P.V. Solid Oxide Fuel Cells fuelled with biogas: Potential and constraints. Renew. Energy 2019, 134, 194-214. [CrossRef]

27. Mohammed, H.; Al-Othman, A.; Nancarrow, P.; Tawalbeh, M.; El Haj Assad, M. Direct hydrocarbon fuel cells: A promising technology for improving energy efficiency. Energy 2019, 172, 207-219. [CrossRef]

28. Gür, T.M. Comprehensive review of methane conversion in solid oxide fuel cells: Prospects for efficient electricity generation from natural gas. Prog. Energy Combust. Sci. 2016, 54, 1-64. [CrossRef]

29. Wang, W.; Su, C.; Wu, Y.; Ran, R.; Shao, Z. Progress in Solid Oxide Fuel Cells with Nickel-Based Anodes Operating on Methane and Related Fuels. Chem. Rev. 2013, 113, 8104-8151. [CrossRef]

30. Meng, Y.; Gao, J.; Zhao, Z.; Amoroso, J.; Tong, J.; Brinkman, K.S. Review: Recent progress in low-temperature proton-conducting ceramics. J. Mater. Sci. 2019, 54, 9291-9312. [CrossRef]

31. Fabbri, E.; Bi, L.; Pergolesi, D.; Traversa, E. Towards the Next Generation of Solid Oxide Fuel Cells Operating Below $600{ }^{\circ} \mathrm{C}$ with Chemically Stable Proton-Conducting Electrolytes. Adv. Mater. 2012, 24, 195-208. [CrossRef]

32. Duan, C.; Huang, J.; Sullivan, N.; O'Hayre, R. Proton-conducting oxides for energy conversion and storage. Appl. Phys. Rev. 2020, 7, 011314. [CrossRef]

33. Konwar, D.; Nguyen, N.T.Q.; Yoon, H.H. Evaluation of $\mathrm{BaZr}_{0.1} \mathrm{Ce}_{0.7} \mathrm{Y}_{0.2} \mathrm{O}_{3-\delta}$ electrolyte prepared by carbonate precipitation for a mixed ion-conducting SOFC. Int. J. Hydrogen Energy 2015, 40, 11651-11658. [CrossRef]

34. Chen, Y.; deGlee, B.; Tang, Y.; Wang, Z.; Zhao, B.; Wei, Y.; Zhang, L.; Yoo, S.; Pei, K.; Kim, J.H.; et al. A robust fuel cell operated on nearly dry methane at $500{ }^{\circ} \mathrm{C}$ enabled by synergistic thermal catalysis and electrocatalysis. Nat. Energy 2018, 3, 1042-1050. [CrossRef]

35. Ormerod, R.M. Solid oxide fuel cells. Chem. Soc. Rev. 2003, 32, 17-28. [CrossRef]

36. Bhide, S.V.; Virkar, A.V. Stability of $\mathrm{BaCeO}_{3}$-Based Proton Conductors in Water-Containing Atmospheres. J. Electrochem. Soc. 1999, 146, 2038-2044. [CrossRef]

37. Babilo, P.; Haile, S.M. Enhanced Sintering of Yttrium-Doped Barium Zirconate by Addition of ZnO. J. Am. Ceram. Soc. 2005, 88, 2362-2368. [CrossRef]

38. Tong, J.; Clark, D.; Hoban, M.; O'Hayre, R. Cost-effective solid-state reactive sintering method for high conductivity proton conducting yttrium-doped barium zirconium ceramics. Solid State Ion. 2010, 181, 496-503. [CrossRef]

39. Takeguchi, T.; Kani, Y.; Yano, T.; Kikuchi, R.; Eguchi, K.; Tsujimoto, K.; Uchida, Y.; Ueno, A.; Omoshiki, K.; Aizawa, M. Study on steam reforming of $\mathrm{CH}_{4}$ and $\mathrm{C}_{2}$ hydrocarbons and carbon deposition on Ni-YSZ cermets. J. Power Sources 2002, 112, 588-595. [CrossRef]

40. Yang, L.; Choi, Y.; Qin, W.; Chen, H.; Blinn, K.; Liu, M.; Liu, P.; Bai, J.; Tyson, T.A.; Liu, M. Promotion of water-mediated carbon removal by nanostructured barium oxide/nickel interfaces in solid oxide fuel cells. Nat. Commun. 2011, 2, 357. [CrossRef]

41. Li, X.; Liu, M.; Lai, S.Y.; Ding, D.; Gong, M.; Lee, J.-P.; Blinn, K.S.; Bu, Y.; Wang, Z.; Bottomley, L.A.; et al. In Situ Probing of the Mechanisms of Coking Resistance on Catalyst-Modified Anodes for Solid Oxide Fuel Cells. Chem. Mater. 2015, 27, 822-828. [CrossRef]

42. Hua, B.; Yan, N.; Li, M.; Sun, Y.-F.; Zhang, Y.-Q.; Li, J.; Etsell, T.; Sarkar, P.; Luo, J.-L. Anode-Engineered Protonic Ceramic Fuel Cell with Excellent Performance and Fuel Compatibility. Adv. Mater. 2016, 28, 8922-8926. [CrossRef] [PubMed]

43. Wang, W.; Chen, Y.; Wang, F.; Tade, M.O.; Shao, Z. Enhanced electrochemical performance, water storage capability and coking resistance of a $\mathrm{Ni}+\mathrm{BaZr}_{0.1} \mathrm{Ce}_{0.7} \mathrm{Y}_{0.1} \mathrm{Yb}_{0.1} \mathrm{O}_{3-\delta}$ anode for solid oxide fuel cells operating on ethanol. Chem. Eng. Sci. 2015, 126, 22-31. [CrossRef]

44. Marrony, M. Proton-Conducting Ceramics: From Fundamentals to Applied Research; CRC Press: Boca Raton, FL, USA, 2015.

45. Zhu, H.; Braun, R.J.; Kee, R.J. Thermodynamic Analysis of Energy Efficiency and Fuel Utilization in Protonic-Ceramic Fuel Cells with Planar Co-Flow Configurations. J. Electrochem. Soc. 2018, 165, F942-F950. [CrossRef]

46. Duan, C.; Kee, R.; Zhu, H.; Sullivan, N.; Zhu, L.; Bian, L.; Jennings, D.; O’Hayre, R. Highly efficient reversible protonic ceramic electrochemical cells for power generation and fuel production. Nat. Energy 2019, 4, 230-240. [CrossRef]

47. Coors, W.G. Protonic ceramic fuel cells for high-efficiency operation with methane. J. Power Sources 2003, 118, 150-156. [CrossRef]

48. Feng, Y.; Luo, J.-L.; Chuang, K.T. Carbon deposition during propane dehydrogenation in a fuel cell. J. Power Sources 2007, 167, 486-490. [CrossRef]

49. Liu, S.; Chuang, K.T.; Luo, J.-L. Double-Layered Perovskite Anode with in Situ Exsolution of a Co-Fe Alloy To Cogenerate Ethylene and Electricity in a Proton-Conducting Ethane Fuel Cell. ACS Catal. 2016, 6, 760-768. [CrossRef]

50. Hua, B.; Yan, N.; Li, M.; Zhang, Y.-Q.; Sun, Y.-F.; Li, J.; Etsell, T.; Sarkar, P.; Chuang, K.; Luo, J.-L. Novel layered solid oxide fuel cells with multiple-twinned $\mathrm{Ni}_{0.8} \mathrm{Co}_{0.2}$ nanoparticles: The key to thermally independent $\mathrm{CO}_{2}$ utilization and power-chemical cogeneration. Energy Environ. Sci. 2016, 9, 207-215. [CrossRef] 
51. Konwar, D.; Park, B.J.; Basumatary, P.; Yoon, H.H. Enhanced performance of solid oxide fuel cells using $\mathrm{BaZr}_{0.2} \mathrm{Ce}_{0.7} \mathrm{Y}_{0.1} \mathrm{O}_{3-\delta}$ thin films. J. Power Sources 2017, 353, 254-259. [CrossRef]

52. Lei, L.; Keels, J.M.; Tao, Z.; Zhang, J.; Chen, F. Thermodynamic and experimental assessment of proton conducting solid oxide fuel cells with internal methane steam reforming. Appl. Energy 2018, 224, 280-288. [CrossRef]

53. Li, M.; Hua, B.; Luo, J.-L.; Jiang, S.P.; Pu, J.; Chi, B.; Li, J. Enhancing Sulfur Tolerance of Ni-Based Cermet Anodes of Solid Oxide Fuel Cells by Ytterbium-Doped Barium Cerate Infiltration. ACS Appl. Mater. Interfaces 2016, 8, 10293-10301. [CrossRef]

54. Li, M.; Hua, B.; Luo, J.-L.; Jiang, S.P.; Pu, J.; Chi, B.; Jian, L. Carbon-tolerant Ni-based cermet anodes modified by proton conducting yttrium- and ytterbium-doped barium cerates for direct methane solid oxide fuel cells. J. Mater. Chem. A 2015, 3, 21609-21617. [CrossRef] 